\title{
English Learning Needs of the Biology Education Department Students
}

\author{
Riana Agustin Tindjabate \\ Email: ra_tindjabate@yahoo.co.id \\ Fakultas Keguruan dan Ilmu Pendidikan, Universitas Kristen \\ Tentena
}

\begin{abstract}
Abstrak
Tujuan penelitian ini adalah untuk mendiskripsikan kebutuhan mahasiswa program studi pendidikan biologi terhadap pembelajaran bahasa Inggris. Penelitian ini dilaksanakan di Universitas Kristen Tentena secara khusus pada Program Studi Pendidikan Biologi. Subyek penelitian adalah 24 orang mahasiswa yang berperan sebagai partisipan. Pengumpulan data dilaksanakan dengan membagikan angket 25-BioSNEL kepada 24 orang partisipan. Data dari hasil penelitian menunjukkan bahwa mahasiswa Program Studi Pendidikan Biologi di Universitas Kristen Tentena sangat membutuhkan pengetahuan tentang istilah-istilah bahasa Inggris yang dipakai dalam bidang pendidikan biologi sedangkan untuk latihan berbahasa Inggris mahasiswa sangat membutuhkan latihan-latihan yang mengajarkan cara menggunakan kosakata bahasa Inggris dalam percakapan sehari-hari. Penelitian ini menyimpulkan bahwa pengajaran bahasa Inggris secara khusus pada bidang pendidikan Biologi harus lebih difokuskan pada pembelajaran tentang kosakata dan istilah-istilah di bidang Biologi serta pembelajaran tentang bagaimana cara menggunakan kosakata bahasa Inggris dalam percakapan.

Kata Kunci: Analisis kebutuhan, kebutuhan terhadap pembelajaran bahasa
\end{abstract}

Abstract

The purpose of this study is to describe learning needs of the students of Biology Education Department on the English learning. The research was conducted at the Christian University of Tentena particularly in the Biology Education Department. The research subjects were 24 students who acted as research participants. The data collection was carried out by distributing questionnaires of the 25-BioSNEL to 24 participants. Data from the research showed that students of Biology Education Department of the Christian University of Tentena needed knowledge about the terms of English used in the field of biology education and for training English speaking students desperately needed exercises that teach them how to use the English vocabulary in daily conversation. The research concluded that the teaching of English in the field of biology education should be more focused on learning about the vocabulary and terms in the field of biology as well as learning about how to use the English vocabulary in conversation.

Key words: Needs analysis, English learning needs

\section{A. INTRODUCTION}

English is an official business language of ASEAN Economic Community

(AEC) as stated in many sources on internet and scientific meetings. It has an important role toward the smoothness of trade and business communication among the ASEAN countries. Indonesia as one of ASEAN members has established English as a foreign language and has taught it as a compulsory subject. However, English is nowadays developed as an unofficial second language which has been used by most of urban people in Jakarta and many of big cities in Indonesia. The people use it as a 
daily language at home, at school, and at office which it probably might be affected by the AEC program which is officially implemented in Indonesia since 2015.

Promoting English as a second language is also supported by tertiary education in Indonesia through curriculum and syllabus development, innovation of English teaching, teaching methods development, human resources development, and materials evaluation. English teachers are given sufficient facilities by the government in order to develop and evaluate their syllabus. They are also motivated by many rewards through the government policy in which they are expected being more professional in and outside the classroom.

Christian University of Tentena which is located in Tentena, Central Sulawesi, Indonesia teaches English as one of general subjects. It is an obligation to the students to make contract of the subject in the particular semesters. English subject is taught as a general subject at seven non English departments in the university; (1) Biology Education Department, (3) Mathematics Education Department, (4) Early Childhood Education Department, (5) Management Department, (6) Department of Development Study, (7) Agribusiness
Department, and (8) Sociology Department. The subject is divided into two parts, initially, English I and English II. These are taught in odd and even semester.

The Biology Education Department is one of the departments which teach English in two semesters. According to the department management, the content of English I subject is materials of general English while in English II the students learn specific English used in the biology field. One of biology lecturers gave her opinion about the importance of English towards students' quality when the researcher did pre-research at the university. The lecturer said that English was needed by students of the Biology Education Department as a tool to communicate internationally their researches and as a tool to get additional information from scientific articles and textbooks which were written in English. The early assumptions of the lecturer are stated based on her teaching experience and reality. Those assumptions could not be denied by most of the students and the teachers.

However, the students' needs on English teaching could not be based only on those assumptions. It should be developed after conducting a set of needs' analysis. The researcher has the milestone of the 
Department Curriculum Development and there is no record of students' need analysis toward English teaching since the department was established in 2007. The researcher obtained information from a lecturer of English for a Specific Purposes (ESP) who has taught ESP in the department. He conducted three steps to arrange and develop syllabus; (1) adapting syllabus from other universities, (2) using self-experience and (3) adopting textbooks. The three steps are not including as needs analysis but simple ways to provide syllabus.

Students of The Biology Education Department have right to get knowledge and skills of English as they need. The current research is important to be conducted in order to give real facts of the students' needs. The English lecturer might be able to produce syllabus based on real needs of the students. This is expected to support the successful of English learning and teaching at the Biology Education Department so that the students are prepared well in facing the AEC impacts. The researcher formulates two research problems as follow; (1) What knowledge of English is strongly needed by students of Biology Education Department at Christian University of Tentena, (2) What practices of English are strongly needed by students of Biology Education Department at Christian University of Tentena. This research is conducted to; (1) Describe knowledge of English which is strongly needed by students of Biology Education Department at Christian University of Tentena, and (2) Describe practices of English which are strongly needed by students of Biology Education Department at Christian University of Tentena.

This research is expected to give three benefits as follow; (1) This research will contribute to the theoretical development of syllabus design of English subject in tertiary education, (2) Practically, this research might be used by the EFL lecturer of the Biology Education Department in evaluating and developing his syllabus based on the students' needs, and (3) This research might be useful as a basis to the researcher in making handout or guidance book of English subject particularly the handout or the guidance book for students of the Biology Education Department.

\section{Research Methods}

This research uses survey method to collect data and quantitative approach to analyze the data. Survey method is used by 
the researcher since the purpose of this research is to describe the BED students' learning needs based on the statements' categories. The current research is conducted at the Christian University of Tentena, Jalan Torulemba Nomor 21, Tentena, Kelurahan Pamona Province of Central Sulawesi, Indonesia.

The research population is 54 students of the BED in academic year of 2015/2016. The students fill in the form with their self-identity such as name, student's register number, age, gender, work experience and year of enrollment. In the research proposal, the researcher determines 54 students of the BED as the samples however only 24 of the students who fill in the questionnaire due to the students' absence at the data collection schedule.

$\mathrm{Li}$ (2014) suggests three considerations when information is gathered from the respondents; (1) reviewing the conditions, (2) paying attention to the scope and (3) considering objectives of the study. Therefore, data of the present research is collected through questionnaire distribution. The questionnaire is called the 25 (twenty five) - Biology Student's Needs of English Learning or in brief form it is called the 25BioSNEL. The questionnaire is an adaptation of theories of needs analysis as suggested by
Hutchinson and Waters (1987); DudleyEvans and ST. John (1998), and Munby in Songhori (2008). The researcher has deeply considered particular and needed elements from the analysts' theories as she wants to focus only on the learning needs.

The questionnaire consists of 25 statements which are divided into six categorizations; (1) students' needs for English tenses, (2) students' needs for English vocabulary, (3) students' needs for listening skills, (4) students' needs for reading skills, (5) students' needs for writing skills, and (6) students' needs for speaking skills. The respondents answer the five choices; (1) strongly disagree, (2) disagree, (3) agree, (4) strongly agree, (5) no idea, for each statement.

Data analysis is carried out by conducting four steps; (1) The researcher checks students' answers for each statement by recording the answer on an answer sheet, (2) The researcher fills in the recapitulation table with students' answers, (3) The researcher calculates the overall percentage of students' answer for each statement and records the percentage on percentage sheet, and (4) The researcher displays the calculation of percentage through bar chart for the final analysis. 


\section{Research Results and Discussions}

Knowledge of general English is strongly needed by the BED students. There are 13 of 24 participants who strongly agree that knowledge of general English is needed in English learning at the BED and 11 participants answer that they agree with the needs. Moreover, the participants state the needs on knowledge of English grammar. There are 15 of 24 participants agree that they should study the knowledge of how to use English grammar in sentences and those are supported by other 9 participants who answer "strongly agree" with the needs.

Another point is that the participants not only need to study the knowledge but they also need to learn how to apply the English grammar in sentences. There are $45.80 \%$ of the participants answering that they need exercises to make grammatical sentences in English and $54.20 \%$ of the participants strongly agree with the need. The implication of this research results is ESP (English for Specific Purposes) teachers at the university should develop their learning method in which the students have many opportunities to make sentence using English grammar.

Vocabulary necessities are important to every language learners including ESP learners. There are $62.50 \%$ of 24 participants who agree to study English vocabulary that can be used every day and $37.50 \%$ of the participants agree with the need. Besides the needs on English vocabulary study, $58.30 \%$ of the participants express their strong agreement (S-6) that they need to study the use of English vocabulary in daily conversation and this agreement is supported by $37.50 \%$ of the participants who agree with the need while $4.20 \%$ of the participants have no idea. In addition, $70.80 \%$ of the participants also state that they strongly need to learn how to apply the vocabulary in sentences and $29.20 \%$ of the participants agree with the need (S-7). Apparently, the high percentages of the participants' needs on English vocabulary and its application in conversation and sentences suggest the ESP teacher to provide suitable vocabulary exercises in their syllabus.

Pronunciation is an important element of speaking particularly in the field of Biology. The present research finds out that pronunciation exercises of English sentences are strongly needed by $50 \%$ of the participants and the others 50\% agree with this need. Moreover, the participants reveal that they also need to practice the English vocabulary pronunciation. Interestingly there are $70.80 \%$ of the participants who 
agree to learn the vocabulary pronunciation and $20.80 \%$ of the participants think that the pronunciation exercises are very important however there are $8.40 \%$ who do not have idea on this need. Although the research results generally describe the participants' needs on pronunciation but there is disagreement in the case of pronunciation exercises through oral presentation. The research results find out that $4.20 \%$ of the participants strongly disagree and $25 \%$ of the participants disagree with the need. In contrast $54.10 \%$ of the participants feel that they need to practice orally the pronunciation as well as the $16.70 \%$ who consider pronunciation exercises through oral presentation are important. The answer of participants about the S-23 is not surprising due to the lack of students' self confidence. Many ESP students prefer to train their pronunciation skills in groups than individually. This is important to be realized for this reason ESP teacher must encourage the students to be able to use English as a learning instruction.

The present research shows high percentage towards English terms in the field of Biology. There are $75 \%$ of the participants who strongly agree with the English terms supply and $25 \%$ of the participants agree with the statement. In addition, the participants also state their needs of knowledge of how to use the English terms in field. It is found that $70.80 \%$ of the participants need the knowledge and $29.20 \%$ of the participants agree with the need. The research results imply that ESP teachers have to design active learning activities in which the learners are able to use the terms contextually.

Nowadays, ESP learning at tertiary level particularly in Indonesia has been moving to more active learning. Listening skills are one of the basic skills of English which must be emphasized in the learning process and this is related to the participants' answer on S-9. The research results show that $58.30 \%$ of the participants need to practices their listening skills through lectures in the field of Biology in which English is used as the language of instruction. Moreover, there are $33.30 \%$ of the participants who emphasize the needs by answering that they strongly agree with the need. More than a half of the participants need lectures in English whereas $8.40 \%$ of the participants disagree with the statement.

Besides listening to lectures, the participants also need to practice their listening skills through seminar in the field of Biology which is delivered in English. 
Even though the need is important but the percentage different among the participants' answers is very thin. There are $29.20 \%$ of the participants who agree and $37.50 \%$ of the participants strongly agree with the need while the rest, $33.30 \%$, is disagree.

Reading skills are necessities in field of studies including in the biology field. Generally, the BED students need technical and practical information of the skills even though there are several students who have no idea about the skills. The research results show that all of the participants need knowledge of reading technique of scientific articles which are written in English (S-12) as well as the need on reading practices of scientific articles particularly in the biology field (S-13). However, there are $8.4 \%$ of the participants who have no idea about the need on knowledge of reading English texts in the field of Biology but $54.10 \%$ of the participants agree and $37.50 \%$ strongly agree with the statement (S-14). The results of S-14 are near to the S-15's results. There are more than a half of the participants agree (58.4\%) even strongly agree (37.5\%) with the need on reading practices of English text particularly in the biology field whereas $4.1 \%$ of the participants has no idea.

In many field of studies, English writing skills are demanded to be learnt since many students must internationally publish their scientific writing before graduation. To be able to produce good scientific work in the sense of international requirements, students should have competence and proficient skills in English writing for instance skills of writing essay, scientific works and practical reports. The research results on two kinds of English writing needs, initially, English writing knowledge and practices show that there is a resistance from the BED students.

The data reveals the percentage of the participants need on English writing knowledge in different productions; essay, scientific work and practical report. There are $70.80 \%$ of the participants supporting the need on knowledge of how to write essay in English (S-17) and 29.20\% of the participants strongly agree with the statement. In S-19, all of the participants agree with the need on scientific writing knowledge as $58.40 \%$ of the participants' answer. This is strongly supported by the $41.60 \%$ of the participants. Interestingly, when the participants are asking about their needs on knowledge of practical reports writing (S-21) there are $16.70 \%$ of the participants who disagree with the statement while $54.10 \%$ of the participants agree, $25 \%$ of the participants strongly agree and $4.20 \%$ 
of the participants have no idea. In general, the data show high percentage on the writing knowledge. The data suggests the ESP teacher to consider seriously what kinds of writing teaching materials that they will take into the ESP class of the BED.

The further data shows the participants' answers on the needs of English writing skills. There are three kinds of academic writing that are asked in the present research. Firstly, the participants have high percentage towards needs on writing practices of essay. In the S-18, $70.80 \%$ of the participants need essay writing practices and $29.20 \%$ of the participants strongly agree with the statement. Secondly, the participants also show high needs on writing practices of scientific works (S-20) otherwise there are participants who disagree with the needs. The percentage of S-20 is as follow; $50 \%$ of the participants agree, $45.80 \%$ of the participants strongly agree while $4.20 \%$ of the participants disagree. Thirdly, the data of S-22 show a medium needs on practices of practical report particularly in the field of biology. There are $37.60 \%$ of the participants who answer "agree", $33.30 \%$ of the participants answer "strongly agree" while $29.10 \%$ of the participants disagree with the statement.
Nowadays, learning English means learning how to use the language. Since many years ago the ESP learning goal has been moving from memorization of English words and translation native language into the target language and vice versa to communication purpose. Particularly, the ESP students learn English so they can use the language as a tool of communication in their field of study and in their real life afterwards. One of basic skills of English that is very needed by the students is speaking.

In the speaking aspect, the participants answer two kinds of question related to the speaking needs. Firstly, there are $45.80 \%$ of the participants who agree that they need speaking practices through oral presentation and $29.10 \%$ of the participants strongly support the statement while $20.90 \%$ of the participants disagree even $4.20 \%$ of the participants strongly disagree with the needs (S-24). Secondly, the participants, in general, answer that they need speaking practices to express their opinions considering learning materials of biology (S-25). There are $45.80 \%$ of the participants who need speaking practices so that they can express their opinion and $25 \%$ of the participants strongly agree with needs. Unfortunately, there are $4.20 \%$ of the 
participants have no idea about the need whereas $25 \%$ of the participants disagree with the needs.

The implication of the present research results is that ESP teaching at the university should be focused on the use of English terms in the field of biology and the use of English vocabulary in daily conversation. Even though the results show that the students highly need knowledge of vocabulary and how to use the vocabulary in conversation however it does not mean that the ESP teachers have less consideration about the teaching of reading, listening, writing and speaking. Those skills must be integrated into the vocabulary teaching.

\section{E. Conclusion and Suggestions}

Firstly, the research results find out that the BED students strongly need knowledge of English terms in the field of biology. The percentage of this need is $75 \%$. It means that ESP teachers of the department should provide sufficient biology terms in English in order to develop the students' knowledge of English vocabulary. Secondly, all of the practices of English are strongly needed by the BED students at average but needs on vocabulary practices through daily conversation has the highest percentage among other needs which is answered by $58.30 \%$ of the participants.

The researcher suggests 3 (three) main points after conducting the current research: (1) ESP teachers at the BED of the Christian University of Tentena should enrich their knowledge of English vocabulary, (2) ESP teachers at the BED of the Christian University of Tentena should develop their proficiency of reading, listening, writing and speaking skills so that they can teach the BED student professionally, and (3) ESP syllabus at the BED of the university should be reviewed in order to meet the BED students' learning of needs.

\section{REFERENCES}

Adamson, John. 2005. From EFL to Content-Based Instruction: what English teachers take with them into the sociolinguistics lecture. The Asian EFL Journal Quarterly. Professional Teaching Articles Collection 2005 (downloaded in April $15^{\text {th }}, 2016$ )

Albert, Agnes and Kormos, Judit. 2004. Language Learning. Creativity and Narrative Task Performance: An Exploratory Study. Sent by Nasmilah Imran (imla63@yahoo.com to Riana Agustin Tindjabate (ra_tindjabate@yahoo.co.id)

Al-Saadi, Said Hamed and Samuel Moses Stephens. 2013. An Analysis of the Writing 
Needs of Omani EFL Students for the Development of Grade 11 English Program. The Asian EFL Journal, Quarterly March 2013, Volume 15, Issue 1 (downloaded in April, 14 ${ }^{\text {th }}$ 2016).

Boshrabadi, Abbas Mehrabi, Biria, Reza, and Nikbakht, Elham. 2015. Critical Evaluation of Lexical Categories in ESP Textbooks Used for Iranian Dentistry Students: The Gap between Perceived and Real Needs. The Asian ESP Journal, December 2015, Volume 11, Issue 2 (downloaded in April, 13 ${ }^{\text {th }}$ 2016).

Brooks, Jacqueline Grennon and Brooks, Martin G. 1999. In search of Understanding. The Case for Constructivist Classrooms Association for Supervision Curriculum Development: Alexandria, USA (eBook).

Dudley-Evans, Tony and St. John, Maggie Joe. 1998. Developments in English for Specific Purposes. Cambridge University Press: Cambridge.

Hutchinson, Tom and Waters, Alan. 1987. English for Specific Purposes. A LearningCentered Approach. Cambridge University Press: Cambridge.

Lü, Pi-Hsia, Rau, D. Victoria \& Wang, YuFang. 2015. Secretarial Needs in a Bicultural Academic Office. The Asian ESP Journal, December 2015, Volume 11, Issue 2 (downloaded in April, 13 ${ }^{\text {th }}$ 2016).

Li, Juan. 2014. Needs Analysis: An Effective Way in Business English Curriculum Design. Theory and Practice in Language Studies, Vol. 4, No. 9, pp. 1869-1874, September 2014 Academy Publisher Manufactured in Finland (downloaded in April $9^{\text {th }}, 2016$ ).
McKay, Sandra Lee. 2002. Teaching English as an International Language.OUP: Oxford.

Meganathan, Ramanujam. 2015. English Language Education Situation in India: Pedagogical Perspectives. Journal of English as an International Language, May 2015, Volume 10, Issue 1 (downloaded in April, $14^{\text {th }}$ 2016)

Sani, Masoumeh Ghorbani, 2015. EFL Teachers' Beliefs about Iranian High School Students' Language Learning Needs. The Iranian EFL Journal, February 2015, Volume 11, Issue 1 (downloaded in April, $10^{\text {th }} 2016$ ).

Phye, Gary D. 1997. Handbook of Academic Learning. Academic Press Inc: USA (eBook)

Pritchard, Alan and Wollard, John. 2010. Psychology for the Classroom: Constructivism and Social Learning. (Online), Taylor and Francis e-Library, (http://www.eBookstore.tandf.co.uk/)

Songhori, Mehdi Haseli. 2008. Introduction to Needs Analysis. English for Specific Purposes World, Issue 4, 2008, www.espworld.info (downloaded on April, $16^{\text {th }}$ 2016). 